\title{
PERSEPSI KEMUDAHAN PENGGUNAAN, PERSEPSI KREDIBILITAS, DAN PERSEPSI HARGA TERHADAP NIAT NABASAH MENGGUNAKAN LAYANAN MOBILE BANKING (STUDI KASUS PADA BANK SYARIAH MANDIRI SURABAYA)')
}

\author{
Reza Ramadhan \\ Mahasiswa Program Studi Ekonomi Islam-Fakultas Ekonomi dan Bisnis-Universitas Airlangga \\ Email: rezaaramadhan@gmail.com
}

Sri Herianingrum

Departemen Ekonomi Syariah-Fakultas Ekonomi dan Bisnis-Universitas Airlangga

Email: sri.herianigrum@feb.unair.ac.id

\begin{abstract}
:
This study aims to discover the impact of Perceived Ease of Use, Perceived Credibility, and Perceived Price in Accordance Intention to Use Mobile Banking. This study uses the Theory Acceptance Model with quantitative approach using the Regression Linear Multivariate. The data source of this study uses primary data from questionnaire. The population characteristic in this study is the Client of Sharia Mandiri Bank that are not using Mobile Banking feature. The sample collecting technique used is Nonprobability Sampling with purposive sampling and accidental sampling. The result of the study shows that Perceived Ease of Use, Perceived Credibility, and Perceived Price in accordance significantly impacting towards the Interest in using the mobile banking feature of Bank Syariah Mandiri Surabaya. Suggestion towards Bank Syariah Mandiri to upgrade the security system to prevent the occurrence of crime trough the mobile banking feature so that the clients will feel safe in using transactions.
\end{abstract}

Keywords: Perceived Ease of Use, Perceived Credibility, Perceived Price, Intention to Use, Mobile Banking.

\section{PENDAHULUAN}

Bank syariah di Indonesia mengalami perkembangan yang cukup pesat, dimana Indonesia merupakan negara dengan mayoritas muslim terbesar di dunia. Masyarakat mulai menyadari akan haramnya riba dalam bank konvensional dan mulai berpaling pada bank syariah yang lebih menekankan pada sistem bagi hasil dan prinsip-prinsip syariah. Allah berfirman dalam Al-Qur'an surat Al-Baqarah ayat 278 :

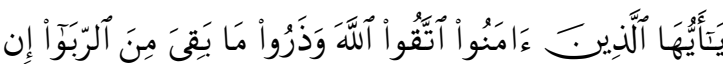

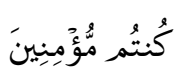

yā-'ayyuhā lladhīna 'āmanū ttaqū Ilāha wa-dharū mā baqiya mina r-ribā in kuntum mu'minīn.

"Hai orang-orang yang beriman, bertakwalah kepada Allah dan tinggalkan sisa Riba (yang belum dipungut) jika kamu orang-orang yang beriman" (QS. Al Baqarah 278).

Bank syariah melihat pemanfaatan teknologi memberikan efektifitas dalam memberikan pelayanan jasa, aspek keamanan dan kemudahan kepada nasabah. Peningkatan kualitas pelayanan jasa yang dilakukan bank syariah yaitu dengan mobile banking .

Mobile banking merupakan layanan jasa yang menggunankan teknologi

1) Jurnal ini merupakan dari skripsi yang ditulis oleh (Reza Ramadhan, 041014099), yang diuji pada 8 Agustus 2016. 
Ramadhan, et al/Jurnal Ekonomi Syariah Teori dan Terapan Vol. 4 No. 6 Juni 2017: 478-492; PERSEPSI KEMUDAHAN PENGGUNAAN, PERSEPSI KREDIBILITAS, DAN PERSEPSI HARGA TERHADAP NIAT NABASAH MENGGUNAKAN LAYANAN MOBILE BANKING (STUDI KASUS PADA BANK SYARIAH MANDIRI SURABAYA)

informasi. Mobile banking atau biasa disebut M-Banking merupakan sutau layanan perbankan yang diberikan pihak bank untuk mendukung kelancaran dan kemudahan kegiatan perbankan.

Salah satu perbankan syariah yang telah mengeluarkan produk jasa ini adalah Bank Syariah Mandiri. Alasan dipilihnya Bank Syariah mandiri sebagai obyek dalam penelitian ini adalah karena Bank Syariah Mandiri merupakan bank yang memiliki banyak nasabah dalam artian merupakan bank yang memiliki pelayanan yang baik kepada nasabahnya. Jumlah nasabah Bank Syariah Mandiri pada tahun 2013 mencapai 4,4 juta nasabah di seluruh Indonesia (www.mandirisyariah.co.id). Bila dilihat pada web Bank Syariah Mandiri lebih memberikan informasi terkait dengan fitur mobile banking dibandingkan dengan bank syariah lainnyaBila diliahat dari penjelasan diatas maka dapat diambil kesimpulan bahwa Bank Syariah Mandiri merupakan bank yang menjunjung tinggi perkembangan teknologi salah satunya adalah mobile banking.

Masyarakat di Indonesia termasuk masyarakat yang paham akan teknologi khususnya telepon seluler. Dengan fasilitas ini, setiap orang yang memiliki ponsel dapat dengan mudah bertransaksi dimana saja dan kapan saja selama ponsel yang digunakan terkoneksi dengan internet. Manfaat lainnya tentu saja dapat mengefisiensi waktu, jika dilihat dalam kehidupan sehari-hari seorang pebisnis tidak membutuhkan waktu yang lama untuk bertransaksi dengan klien bila ingin bertransaksi cukup melalui ponsel, hal ini sangat menghemat waktu bila dibanding dengan pergi ke bank terdekat untuk bertransaksi. Teori yang digunakan untuk mendukung penelitian ini adalah persepsi kemudahan penggunaan.

Pada penelitian ini ini juga menggunakan teori persepsi kredibilitas sebagai faktor yang mencerminkan keamanan dan privasi penggunaan mobile banking. Alasan keamanan tentu saja karena banyaknya penipuan dan pencurian data dalam penggunaan mobile banking, nasabah akan diberikan sandi sebelum melakukan transaksi. Bank syariah tentu saja memegang peranan penting dalam mengamankan data dari nasabah, artinya bank syariah harus memegang amanah yang diberikan nasabah, sehingga mengurangi kemungkinan terjadinya penipuan maupun pencurian data nasabah. Penggunaan jasa mobile banking tentu saja dibebankan harga namun harga yang dikenakan sebanding dengan kualitas pelayanan yang diberikan, hal ini tentu saja tidak memberatkan nasabah maupun bank selaku penyedia jasa. Dalam menentukan harga secara Islami, perusahaan harus mengutamakan nilai keadilan (Kartajaya, 2006: 178). Kutipan dari Kartajaya dikaitkan dengan teori persepsi harga.

Berkat adanya fasilitas mobile banking seperti yang dijelaskan sebelumnya, orang-orang yang sibuk 
Ramadhan, et al/Jurnal Ekonomi Syariah Teori dan Terapan Vol. 4 No. 6 Juni 2017: 478-492; PERSEPSI KEMUDAHAN PENGGUNAAN, PERSEPSI KREDIBILITAS, DAN PERSEPSI HARGA TERHADAP NIAT NABASAH MENGGUNAKAN LAYANAN MOBILE BANKING (STUDI KASUS PADA BANK SYARIAH MANDIRI SURABAYA)

bekerja dan tidak memiliki banyak waktu untuk pergi ke bank, saat ini dapat dengan mudah melakukan transaksi finansialnya dimana saja dan kapan saja selama terhubung dengan internet. Namun kenyataannya, masih ada nasabah yang belum memanfaatkan adanya layanan mobile banking yang disediakan oleh bank tersebut. Oleh karena itu, penulis merasa tertarik untuk melakukan penelitian yang berkaitan dengan persepsi. Persepsi pada umumnya merupakan proses penilaian seseorang terhadap obyek tertentu. Pada penelitian ini, peneliti menggunakan persepsi kemudahaan penggunaan, persepsi kredibilitas, dan persepsi harga. Adanya persepsi tersebut akan menimbulkan niat nasabah untuk memutuskan apakah akan meggunakan mobile banking ataupun tidak. Dengan adanya penelitian ini, akan diketahui persepsi apa saja yang menjadikan nasabah memutuskan untuk menggunakan fasilitas mobile banking dan akan terlihat pula persepsi mana yang paling mempengaruhi dalam niat nasabah menggunakan mobile banking.

Penelitian ini ingin mengetahui seberapa besar pengaruh persepsi kemudahan penggunaan, persepsi kredibilitas, dan persepsi harga secara simultan terhadap niat nasabah menggunakan mobile banking dan pengaruh persepsi kemudahan penggunaan, persepsi kredibilitas, dan persepsi harga secara parsial terhadap niat nasabah menggunakan mobile banking. Berdasarkan uraian tersebut, maka rumusan masalah dalam penelitian ini adalah: Apakah persepsi kemudahan penggunaan, persepsi kredibilitas, dan persepsi harga secara simultan memiliki pengaruh terhadap niat nasabah menggunakan mobile banking? Apakah persepsi kemudahan penggunaan, persepsi kredibilitas, dan persepsi harga secara parsial memiliki pengaruh terhadap niat nasabah menggunakan mobile banking?

\section{LANDASAN TEORI}

Technology Acceptance Model merupakan pengembangan teori dari Theory of Reasoned Action (TRA) dan Theory of Planned. Technology Acceptance Model (TAM) dikembangkan pertama kali oleh Davis pada tahun 1989, sebagai model penerimaan pengguna pada suatu sistem informasi. TAM memiliki tujuan untuk memberikan penjelasan secara bagian-bagian atas faktor penentu adopsi dari perilaku pengguna teknologi informasi terhadap penerimaan pengguna teknologi informasi itu sendiri (Davis et al, 1989).

Persepsi kemudahan merupakan tingkatan dimana seseorang percaya bahwa teknologi mudah untuk dipahami. Persepsi kemudahan penggunaan didefiniskan sebagai tingkat dimana seseorang percaya bahwa menggunakan sistem tertentu akan bebas dari usaha (Davis, 1989). Sistem yang mudah digunakan akan meningkatkan niat untuk menggunakan sebagai kebalikan dari suatu sistem yang lebih mudah digunakan. 
Ramadhan, et al/Jurnal Ekonomi Syariah Teori dan Terapan Vol. 4 No. 6 Juni 2017: 478-492; PERSEPSI KEMUDAHAN PENGGUNAAN, PERSEPSI KREDIBILITAS, DAN PERSEPSI HARGA TERHADAP NIAT NABASAH MENGGUNAKAN LAYANAN MOBILE BANKING (STUDI KASUS PADA BANK SYARIAH MANDIRI SURABAYA)

Persepsi Kredibilitas merupakan faktor yang mencerminkan keamanan dan privasi pengguna. Persepsi kredibilitas didefinisikan oleh Wang, et al (2003) sebagai perilaku dimana seseorang percaya transaksi dan privasi informasi mereka dijaga dengan aman yang akan mempengaruh penerimaan mereka terhadap suatu sistem teknologi. Keamanan kepada perlindungan informasi atau sistem pengguna dari penipuan atau tindak kejahatan lainnya. Persepsi kredibilitas perlu ditambahkan karena Persepsi kredibilitas telah terbukti secara empiris mempengaruhi user acceptance (Wang et al., 2003). Selain itu alasan menambahkan variabel Persepsi kredibilitas karena banyaknya modus penipuan serta pengaman apabila terjadi kesalahan yang tidak disengaja.

Harga menurut Kotler (2001: 439) harga adalah sejumlah vang yang dibebankan atas suatu produk atau jasa, atau jumlah dari nilai yang ditukar konsumen atas manfaat-manfaat karena memiliki atau menggunakan produk atau jasa tersebut. Persepsi harga berkaitan dengan bagaimana informasi harga dipahami seutuhnya dan memberikan makna yang dalam oleh konsumen. Persepsi harga menjadi sebuah penilaian konsumen tentang perbandingan besarnya pengorbanan dengan apa yang akan didapatkan dari produk dan jasa (Zeithmal, 1988). Konsumen cenderung menggunakan harga sebagai indikator kualitas (Mowen, 1993).
Dalam menentukan harga, perusahaan harus mengutamakan nilai keadilan. Jika kualitas produknya bagus, harganya tentu bisa tinggi. . Sebaliknya jika seseorang telah mengetahui keburukan yang ada dibalik peroduk yang ditawarkan, harganya pun harus disesuaikan dengan kondisi produk tersebut (Kartajaya, 2006: 178). Bagi konsumen, harga merupakan faktor yang menentukan dalam pengambilan keputusan untuk membeli suatu produk atau tidak. Konsumen memutuskan membeli suatu produk jika manfaat yang dirasakan lebih besar atau sama dengan yang dikeluarkan untuk mendapatkannya (Kasmir, 2004).

Niat ini tercermin dari seberapa besar keinginan untuk mencoba dan seberapa kuat usaha yang dialokasikan untuk mewujudkan perilaku tertentu (Ajzen, 1991:181). Niat perilaku merupakan tingkat seseorang untuk mengguakan teknologi informasi baru (Tsai, 2012:56). Davis dalam (Tsai, 2012:56) berpendapat bahwa ketika seseorang memiliki sikap positif terhadap menggunakan teknologi informasi baru, maka niat menggunakan teknologi tersebut juga akan tinggi.

Model Analisis dan Hipotesis

$$
\text { Penelitian ini menggunakan }
$$
Technology Acceptance Model dari Luarn (2005) yaitu merupakan model pengembangan dari model Davis (1989). Alasan penggunaan model Luarn karena penelitian tersebut lebih lengkap dibandingkan dengan penelitian terdahulu dan terbaru. 
Ramadhan, et al/Jurnal Ekonomi Syariah Teori dan Terapan Vol. 4 No. 6 Juni 2017: 478-492; PERSEPSI KEMUDAHAN PENGGUNAAN, PERSEPSI KREDIBILITAS, DAN PERSEPSI HARGA TERHADAP NIAT NABASAH MENGGUNAKAN LAYANAN MOBILE BANKING (STUDI KASUS PADA BANK SYARIAH MANDIRI SURABAYA)

Dalam kajiannya, teori ini merupakan teori konvensional sehingga indikator dari variabel-variabel dalam penelitian ini merupakan hasil sintesa dari indikator yang dikemukakan oleh Luarn (2005) yang kemudian disesuaikan dengan kondisi-kondisi yang memenuhi perspektif Islam.

Wang et al (2003) melakukan penelitian yang berjudul "Determinants of User Acceptance of Internet Banking: an Empirical Study" tujuan yang ingin dicapai pada pada penelitian ini adalah untuk mengetahui faktor-faktor yang mempengaruhi niat menggunakan internet banking dengan menggunakan kerangka Technology Acceptance Model. Variabel yang digunakan dalam penelitian ini adalah computer selfefficacy, perceived usefulness, perceived ease of use, perceived credibility dan behavioran intention. Penelitian serupa juga pernah diteliti oleh Pin Luarn (2005) melakukan penelitian yang berjudul "Toward an Understanding of The Behavioral Intention to Use Mobile Banking" tujuan dari penelitian ini untuk mengetahui faktor-faktor yang mempengaruhi niat menggunakan mobile banking dengan menggunakan model Techonology Acceptance Model. Variabel yang digunakan telah dikembangkan yaitu perceived usefulness, perceived ease of use, perceive credibility, perceived selfefficacy dan perceived financial cost.

Sri Maharsi (2007) melakukan penelitian mengenai faktor-faktor yang mempengaruhi minat menggunakan internet banking yang berjudul "FaktorFaktor yang Mempengaruhi Minat Nasabah Menggunakan Internet Banking dengan Menggunakan Kerangka Technology Acceptance Model (TAM)" membahas tentang faktor yang mempengaruhi minat menggunakan internet banking di 8 bank di Surabaya. Hasilnya, variabel yang digunakan berpengaruh signifikan terhadap minat menggunakan internet banking.

Selain itu penelitian serupa yang menggunakan TAM juga pernah dilakukan oleh Hanung Cokro Kusumo (2010) melakukan penelitian yang berjudul "Analisis Penerimaan Mobile Banking (M-Banking) Dengan Kerumitan (complexity) sebagai Variabel Eksternal Dengan Menggunakan Pendekatan Technology Acceptance Model (TAM)" menunjukkan bahwa variabel yang digunakan berpengaruh signifikan terhadap penerimaan mobile banking.

Hipotesis dalam penelitian ini adalah $\mathrm{H}$ : Persepsi kemudahan penggunaan, persepsi kredibilitas dan persepsi harga berpengaruh signifikan secara simultan terhadap niat nasabah menggunakan mobile banking dan Persepsi kemudahan penggunaan, persepsi kredibilitas dan persepsi harga berpengaruh signifikan secara parsial terhadap niat nasabah menggunakan mobile banking dengan model analisis yaitu:

$$
Y=X+\beta_{1} X_{1}+\beta_{2} X_{2}+\beta_{3} X_{3+} e
$$


Ramadhan, et al/Jurnal Ekonomi Syariah Teori dan Terapan Vol. 4 No. 6 Juni 2017: 478-492; PERSEPSI KEMUDAHAN PENGGUNAAN, PERSEPSI KREDIBILITAS, DAN PERSEPSI HARGA TERHADAP NIAT NABASAH MENGGUNAKAN LAYANAN MOBILE BANKING (STUDI KASUS PADA BANK SYARIAH MANDIRI SURABAYA)

Keterangan :

Y $\quad=$ Niat nasabah Menggunakan

mobile banking (MB)

$B_{1 \ldots} \beta_{3}=$ Koefisien regresi

$\mathrm{X}_{1}=$ Persepsi Kemudahan

Penggunaan (PEU)

$\mathrm{X}_{2} \quad=$ Persepsi Kredibilitas (PC)

$\mathrm{X}_{3}=$ Persepsi Harga (PP)

$\mathrm{e} \quad=$ error term

\section{METODE PENELITIAN}

Penelitian ini menggunakan variabel penelitian antara lain: Persepsi Kemudahan Penggunaan (X1), Persepsi Kredibilitas (X2) dan Persepsi Harga (X3) sebagai variabel eksogen dan Niat nasabah menggunakan layanan Mobile Banking pada Bank Syariah Mandiri Surabaya (Y) sebagai variabel endogen. Variabel Persepsi Kemudahan Penggunaan terdiri dari 4 indikator yang digunakan sebagai item pertanyaan. Variabel Persepsi Kredibilitas terdiri dari 3 indikator yang digunakan sebagai item pertanyaan. Variabel Persepsi Harga terdiri dari 2 indikator yang digunakan sebagai item pertanyaan. Sedangkan Niat nasabah menggunakan layanan Mobile Banking pada Bank Syariah Mandiri Surabaya terdiri dari 2 indikator yang juga digunakan sebagai butir item pertanyaannya.

Skala pengukuran dalam penelitian ini adalah dengan model skala likert yang dimodifikasi sehingga menggunakan empat jawaban, yaitu: (SS) Sangat setuju skor 4, (S) Setuju skor 3, (TS) Tidak setuju skor 2. (STS) Sangat tidak setuju skor 1. Sumber data yang digunakan adalah data primer diperoleh melalui daftar pertanyaan kuesioner yang telah diisi oleh responden dan data sekunder sebagai pendukung yaitu berupa jurnal, foto dokumentasi, internet dan literatur yang berhubungan dengan permasalahan yang diteliti.

Populasi dalam penelitian ini adalah seluruh nasabah Bank Syariah Mandiri yang belum pernah menggunakan Layanan Mandiri Mobile Banking namun sudah mengetahui layanan Mobile Banking di kawasan Surabaya. Adapun karakteristik sampel yang digunakan adalah semua nasabah Bank Syariah Mandiri yang belum menggunakan Layanan Mobile Banking namun telah mengetahui layanan Mobile Banking.

Teknik pengambilan sampel dalam penelitian ini adalah Non Probability Sampling yaitu teknik pengambilan sampel yang tidak memberikan peluang atau kesempatan yang sama bagi setiap unsur atau anggota populasi untuk dipilih menjadi sampel (Sugiyono, 2012:84). Teknik penentuan sampel yang digunakan adalah dengan Teknik penentuan sampel purposive sampling dan aksidental sampling. Menggunakan purposive sampling karena dengan sampel pada penelitian ini ialah nasabah Bank Syariah Mandiri Surabaya oleh karena itu dengan pertimbangan dan kriteria memilih nasabah yang sudah menjadi nasabah Bank Syariah Mandiri dan belum pernah menggunakan layanan mobile banking namun telah mengetahui layanan mobile banking. Sedangkan aksidental sampling 
Ramadhan, et al/Jurnal Ekonomi Syariah Teori dan Terapan Vol. 4 No. 6 Juni 2017: 478-492; PERSEPSI KEMUDAHAN PENGGUNAAN, PERSEPSI KREDIBILITAS, DAN PERSEPSI HARGA TERHADAP NIAT NABASAH MENGGUNAKAN LAYANAN MOBILE BANKING (STUDI KASUS PADA BANK SYARIAH MANDIRI SURABAYA)

adalah teknik penentuan sampel berdasarkan kebetulan, yaitu siapa saja yang secara kebetulan bertemu dengan peneliti dapat digunakan sebagai sampel, bila di pandang orang yang kebetulan ditemui cocok sebagi sumber data (Sugiyono, 2012:85).

Jumlah kuesioner yang disebar menggunakan pendapat Ferdinand, (2006) yaitu dalam penelitian Multivariate (termasuk yang menggunakan analisis regresi berganda) besarnya sampel ditentukan sebanyak 25 kali variabel independen. Dalam penelitian ini terdapat 4 variabel independen $25 \times 4$ (jumlah variable bebas) $=100$ sampel. Sampel penelitian ini sebanyak 100 orang yang sebelumnya belum pernah menggunakan mobile banking di Bank Syariah Mandiri Surabaya.

Data-data yang telah dikumpulkan dalam penelitian ini kemudian diolah lebih lanjut untuk dapat dijadikan bahan penelitian. Adapun proses yang dilakukan dengan cara Koding, Tabulasi, dan Analisis Statistik.

Uji validitas dalam penelitian ini menggunakan uji corrected item-total correlation yang keseluruhan variabelnya dianggap valid karena indikator-indikator pada variabel >0,3. Uji reliabilitas menggunakan Alpha Cronbach yang keseluruhan variabelnya menghasilkan Alpha di atas 0,6 sehingga dianggap reliabel.

Teknik analisis yang digunakan dalam penelitian ini adalah teknik analisis regresi berganda. Analisis regresi linear berganda adalah analisis terhadap model regresi yang memiliki lebih dari satu variabel eksogen. Teknik analisis ini dilakukan menggunakan program SPSS.

\section{HASIL PENELITIAN DAN PEMBAHASAN}

Adapun hasil pengolahan analisis regresi linier berganda variabel PEU, PC, dan PP terhadap minat menggunakan mobile banking (MB) dapat dilihat pada tabel di bawah ini :

Tabel 1.

Hasil Uji Regresi Linier Berganda

\begin{tabular}{|c|c|}
\hline Variabel bebas & Koefisien regresi \\
\hline Konstanta & 0.365 \\
\hline $\operatorname{PEU}\left(X_{1}\right)$ & 0.353 \\
\hline$P C\left(X_{2}\right)$ & 0.270 \\
\hline $\mathrm{PP}\left(\mathrm{X}_{3}\right)$ & 0.308 \\
\hline
\end{tabular}
(diolah)

Berdasarkan hasil perhitungan regresi diatas maka dapat dirumuskan persamaan regresi sebagai berikut: $Y=0.365+0.353 X_{1}+0.270 X_{2}+0.308 X_{3}+e$ Dari persamaan regresi di atas dapat diperoleh penjelasan sebagai berikut :

1. $X_{0}=0.365$

Menunjukkan besarnya nilai niat nasabah menggunakan mobile banking $(M B)(Y)$. Jika variabel variabel PU, PEU dan PP sama dengan nol atau konstan, maka $Y$ sebesar 0.365 .

2. $X_{1}=0.353$

Koefisien regresi variabel persepsi kemudahan penggunaan $\left(X_{1}\right)$ sebesar 0,353 menunjukkan bahwa setiap peningkatan variabel persepsi kemudahan penggunaan ( $\left.X_{1}\right)$, maka niat nasabah menggunakan mobile banking akan meningkat dengan koefisien regresi 
Ramadhan, et al/Jurnal Ekonomi Syariah Teori dan Terapan Vol. 4 No. 6 Juni 2017: 478-492; PERSEPSI KEMUDAHAN PENGGUNAAN, PERSEPSI KREDIBILITAS, DAN PERSEPSI HARGA TERHADAP NIAT NABASAH MENGGUNAKAN LAYANAN MOBILE BANKING (STUDI KASUS PADA BANK SYARIAH MANDIRI SURABAYA)

0,353 dan dengan asumsi variabel lain konstan.

3. $\mathrm{X}_{2}=0.270$

Koefisien regresi variabel persepsi kredibilitas $\left(X_{2}\right)$ sebesar 0,27 menunjukkan bahwa setiap peningkatan variabel persepsi kredibilitas $\left(X_{2}\right)$, maka niat nasabah menggunakan mobile banking akan meningkat dengan koefisien regresi 0,27 dan dengan asumsi variabel lain konstan.

\section{4. $X_{2}=0.308$}

Koefisien regresi variabel persepsi harga (X) sebesar 0,308 menunjukkan bahwa setiap peningkatan variabel persepsi harga $\left(X_{3}\right)$, maka niat nasabah menggunakan mobile banking akan meningkat dengan koefisien regresi 0,308 dan dengan asumsi variabel lain konstan.

\section{A. Hasil Pengujian Asumsi Klasik Atas}

\section{Model Analisis}

\section{a. Uji Multikolinearitas}

Multikolinearitas merupakan uji asumsi klasik yang menandakan suatu situasi dimana terdapat hubungan linear yang hampir sempurna diantara beberapa atau semua variabel independen yang ada. Suatu model regresi dikatakan baik dan dapat ditarik kesimpulan apabila bebas dari penyimpangan atau bebas dari multikolinearitas, sehingga tidak terdapat korelasi diantara variabel independen. Uji multikolinearitas ini dapat dilakukan dengan mendeteksi nilai Variance Inflating Factor (VIF). Dimana jika semakin besar nilai VIF, maka variabel independen tersebut dapat dikatakan semakin bermasalah

atau terdapat multikolinearitas diantara variabel independen. Selain Variance Inflating Factor (VIF), harus mendeteksi nilai tolerance dengan perhitungan SPSS. Ketentuan dari uji multikolinearitas adalah sebagai berikut:

1. Jika nilai Variance Inflating Factor (VIF) lebih dari 10 dan nilai tolerance kurang dari 0,1 maka terjadi multikolinearitas.

2. Jika nilai Variance Inflating Factor (VIF) kurang dari 10 dan nilai tolerance lebih dari 0,1 maka tidak terjadi multikolinearitas.

Adapun nilai VIF yang dihasilkan oleh variabel Persepsi Kemudahan Penggunaan (PEU), Persepsi Kredibilitas (PC), Persepsi Harga (PP) terhadap niat nasabah menggunakan mobile banking (MB) adalah sebagai berikut :

Tabel 2.

Uji Multikolinieritas Variabel Bebas

\begin{tabular}{|c|c|c|}
\hline $\begin{array}{c}\text { Variabel-Variabel } \\
\text { Penelitian }\end{array}$ & IF & Keterangan \\
\hline $\begin{array}{c}\text { Persepsi Kemudahan } \\
\text { Penggunaan }\left(X_{1}\right)\end{array}$ & .500 & $\begin{array}{c}\text { Tidak ada } \\
\text { multikolinearitas }\end{array}$ \\
\hline $\begin{array}{c}\text { Persepsi Kredibilitas } \\
\left(X_{2}\right)\end{array}$ & .758 & $\begin{array}{c}\text { Tidak ada } \\
\text { multikolinearitas }\end{array}$ \\
\hline $\begin{array}{c}\text { Pidak ada } \\
\text { Persepsi Harga }\left(X_{3}\right)\end{array}$ & .515 & multikolinearitas \\
\hline
\end{tabular}

Sumber: Hasil Penelitian, 2016 (diolah)

Tabel 3 menunjukkan bahwa antar variabel bebas tidak terjadi multikolinieritas, dilihat dari nilai VIF pada variabel Persepsi Kemudahan Penggunaan, Persepsi Kredibilitas, Persepsi Harga terhadap niat nasabah menggunakan mobile banking yang kurang dari angka 10.

\section{b. Uji Heteroskedastisitas}


Ramadhan, et al/Jurnal Ekonomi Syariah Teori dan Terapan Vol. 4 No. 6 Juni 2017: 478-492; PERSEPSI KEMUDAHAN PENGGUNAAN, PERSEPSI KREDIBILITAS, DAN PERSEPSI HARGA TERHADAP NIAT NABASAH MENGGUNAKAN LAYANAN MOBILE BANKING (STUDI KASUS PADA BANK SYARIAH MANDIRI SURABAYA)

Uji ini dimaksudkan untuk mengetahui apakah terjadi penyimpangan model karena varian terganggu berbeda antara satu observasi ke observasi lain. Jika yang terjadi pada model adalah gejala homoskedastisitas, berarti tidak terjadi hubungan antara variabel pengganggu dengan variabel bebas, sehingga variabel tergantung benar-benar hanya dijelaskan oleh variabel bebasnya. Gejala heterokedastisitas ini diketahui dengan menggunakan metode analisis korelasi Rank Spearman. Jika nilai signifikansi pada hasil korelasi lebih besar dari 0,05 ( $p>0,05)$ maka dapat dikatakan item bebas dari gejala heterokedastisitas atau terjadi homokedastisitas.

Adapun hasil uji heteroskedastisitas pada variabel Persepsi Kemudahan Penggunaan (PEU), Persepsi Kredibilitas (PC), Persepsi Harga (PP) terhadap niat nasabah menggunakan mobile banking (MB) adalah sebagai berikut :

Tabel 3.

Uji Heteroskedastisitas Rank Spearman

\begin{tabular}{|c|c|c|c|}
\hline $\begin{array}{c}\text { Variabel } \\
\text { Penelitian }\end{array}$ & $\begin{array}{c}\text { Korelasi } \\
\text { Rank } \\
\text { Spearman }\end{array}$ & $\begin{array}{c}\text { P- } \\
\text { value }\end{array}$ & Keterangan \\
\hline $\begin{array}{c}\text { Persepsi } \\
\text { Kemudahan } \\
\text { Penggunaan } \\
\left(X_{1}\right)\end{array}$ & 0.106 & 0.292 & $\begin{array}{c}\text { Tidak terjadi } \\
\text { heteroskedastisitas }\end{array}$ \\
\hline $\begin{array}{c}\text { Persepsi } \\
\text { Kredibilitas }\left(X_{2}\right)\end{array}$ & 0.047 & 0.640 & $\begin{array}{c}\text { Tidak terjadi } \\
\text { heteroskedastisitas }\end{array}$ \\
\hline $\begin{array}{c}\text { Persepsi Harga } \\
\left(X_{3}\right)\end{array}$ & 0.056 & 0.579 & $\begin{array}{c}\text { Tidak terjadi } \\
\text { heteroskedastisitas }\end{array}$ \\
\hline
\end{tabular}

Sumber: Hasil Penelitian, 2016 (diolah)

Tabel 4 menunjukkan bahwa antar residual dengan variabel bebas tidak terjadi heteroskedastisitas, hal tersebut dapat dilihat dari tingkat signifikan pada variabel X1, X2, X3 terhadap Y yang lebih dari $5 \%$.

\section{B. Uji Normalitas}

Uji normalitas pada penelitian ini diberlakukan pada $U_{i}$ (residual), apabila residual $\left(\mathrm{U}_{\mathrm{i}}\right)$ berdistribusi normal dengan sendirinya seluruh variabel penelitian yang digunakan akan berdistribusi normal. Berikut ini hasil uji normalitas pada residual:

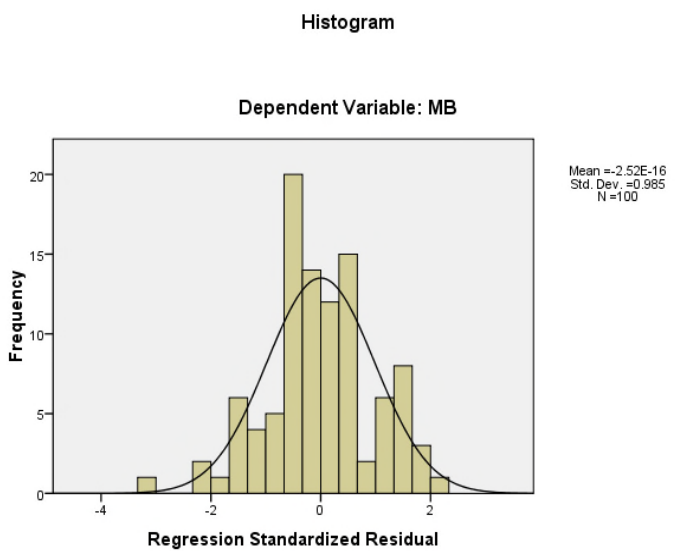

Normal P-P Plot of Regression Standardized Residual

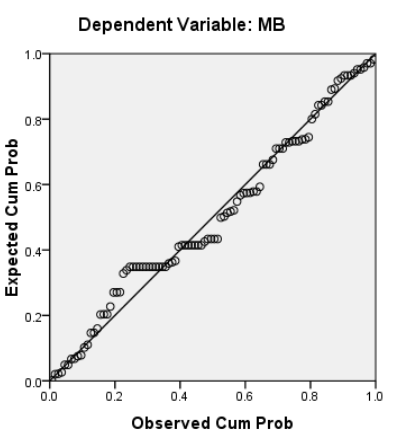

Gambar 1.

Grafik Normalitas

Sumber: Hasil Penelitian, 2016 (diolah) Gambar 2 menunjukkan bahwa residual telah memenuhi asumsi normal. Hal itu dapat dilihat dari gambar 4.3 yang menunjukkan bahwa plot-plot residual berada di sekitar garis normal. Untuk mengetahui secara pasti apakah residual benar-benar berdistribusi normal, maka 
Ramadhan, et al/Jurnal Ekonomi Syariah Teori dan Terapan Vol. 4 No. 6 Juni 2017: 478-492; PERSEPSI KEMUDAHAN PENGGUNAAN, PERSEPSI KREDIBILITAS, DAN PERSEPSI HARGA TERHADAP NIAT NABASAH MENGGUNAKAN LAYANAN MOBILE BANKING (STUDI KASUS PADA BANK SYARIAH MANDIRI SURABAYA)

secara statistik dapat dilihat pada tabel berikut:

Tabel 4.

Hasil Uji Normalitas

One-Sample Kolmogorov-Smirnov Test

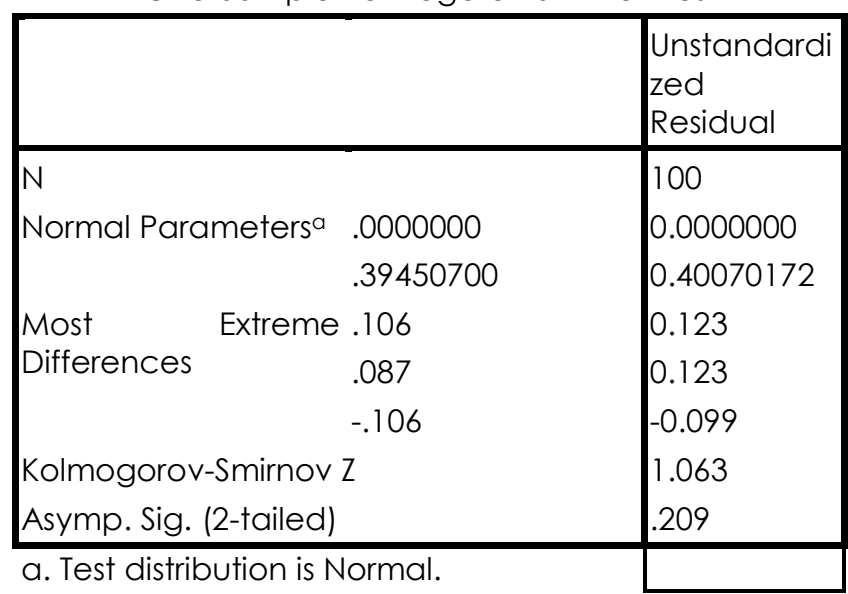

Sumber: Hasil Penelitian, 2016 (diolah)

Tabel 5 menunjukkan bahwa distribusi data pada residual adalah telah memenuhi distribusi normal, karena nilai Kolmogorov-Smirnov yang dihasilkan 1.063 dengan tingkat signifikan sebesar 0.209 lebih dari 5\%. Apabila residual $\left(U_{i}\right)$ telah berdistribusi normal dengan sendirinya variabel persepsi kemudahan penggunaan, persepsi kredibilitas, persepsi harga terhadap niat nasabah menggunakan mobile banking juga berdistribusi normal.

\section{Hasil Pengujian Hipotesis \\ a. Uji F}

Uji F dilakukan untuk mengetahui pengaruh simultan dari variabel-variabel bebas terhadap variabel terikat. Uji $F$ ini dilakukan dengan nilai signifikansi $<0.05$ maka variabel Persepsi Kemudahan Penggunaan (X1), Persepsi Kredibilitas (X2), Persepsi Harga (X3) berpengaruh secara simultan terhadap variabel terikat niat nasabah menggunakan mobile banking (Y). Dapat dilihat dari tabel berikut ini:

Tabel 5.

Hasil Uji F

\begin{tabular}{|c|c|c|c|c|c|}
\hline \multicolumn{1}{|c|}{ Model } & $\begin{array}{c}\text { Sum of } \\
\text { Squares }\end{array}$ & Df & $\begin{array}{c}\text { Mean } \\
\text { Square }\end{array}$ & $\begin{array}{c}\text { F.hitun } \\
\mathbf{g}\end{array}$ & Sig. \\
\hline $1 \quad \begin{array}{c}\text { Regressi } \\
\text { on }\end{array}$ & 11.732 & 3 & 3.911 & 24.366 & $0.000 a$ \\
$\begin{array}{r}\text { Residual } \\
\text { Total }\end{array}$ & 15.408 & 96 & 0.160 & & \\
& 27.140 & 99 & & & \\
\hline
\end{tabular}

Sumber: Hasil Penelitian, 2016 (diolah)

Tabel 6 menunjukkan bahwa nilai $\mathrm{F}$ hitung sebesar 24.366 dengan tingkat signifikan lebih kecil dari $5 \%$ yaitu sebesar 0,000 . Hal ini berarti model regresi yang dihasilkan adalah cocok atau sesuai untuk mengetahui pengaruh variabel Persepsi Kemudahan Penggunaan (PEU), Persepsi Kredibilitas (PC), Persepsi Harga (PP) terhadap niat nasabah menggunakan mobile banking (MB).

\section{b. Uji $t$}

Uji † dilakukan Untuk mengetahui ada tidaknya pengaruh parsial variabel bebas $X_{1} \quad$ (Persepsi Kemudahaan Penggunaan), $X_{2}$ (Persepsi Kredibilitas), $X_{3}$ (Persepsi Harga) berpengaruh terhadap variabel terikat $Y$ (Niat Nasabah Menggunakan Mobile Banking). Penentuan diterima atau tidaknya pengujian secara parsial dapat diketahui dari nilai signifikansi uji † yang lebih kecil dari 0,05. Berdasarkan asumsi tersebut maka keputusan untuk ada tidaknya pengaruh pada masing-masing variabel adalah sebagai berikut:

Tabel 6. 
Ramadhan, et al/Jurnal Ekonomi Syariah Teori dan Terapan Vol. 4 No. 6 Juni 2017: 478-492; PERSEPSI KEMUDAHAN PENGGUNAAN, PERSEPSI KREDIBILITAS, DAN PERSEPSI HARGA TERHADAP NIAT NABASAH MENGGUNAKAN LAYANAN MOBILE BANKING (STUDI KASUS PADA BANK SYARIAH MANDIRI SURABAYA)

\begin{tabular}{|c|c|c|c|}
\hline \multicolumn{5}{|c}{ Hasil Uji $\dagger$} \\
\hline $\begin{array}{c}\text { Variabel } \\
\text { Kersepsi } \\
\text { Kemudahaan } \\
\text { Penggunaan } \\
\left(\mathrm{X}_{1}\right)\end{array}$ & 3.245 & $\begin{array}{c}\text { Tingkat } \\
\text { signifikan }\end{array}$ & Kesimpulan \\
\hline $\begin{array}{c}\text { Persepsi } \\
\text { Kredibilitas } \\
\left(\mathrm{X}_{2}\right)\end{array}$ & 2.226 & 0.002 & $\begin{array}{c}\text { Berpengaruh } \\
\text { Signifikan }\end{array}$ \\
\hline $\begin{array}{c}\text { Persepsi } \\
\text { Harga }\left(\mathrm{X}_{3}\right)\end{array}$ & 2.808 & 0.006 & $\begin{array}{c}\text { Berpengaruh } \\
\text { Signifikan } \\
\text { Signifikan }\end{array}$ \\
\hline
\end{tabular}

Sumber: Hasil Penelitian, 2016 (diolah)

Berdasarkan tabel 7 Menunjukkan bahwa variabel Persepsi Kemudahan Penggunaan, Persepsi Kredibilitas, dan Persepsi Harga bepengaruh secara parsial terhadap variabel Niat Nasabah Menggunakan Mobile Banking. Hal ini dapat dilihat dari nilai thitung masing-masing variabel yang dihasilkan dan tingkat signifikan yang kurang dari 0,05.

\section{Pembahasan}

\section{a. Pengaruh Persepsi Kemudahan}

Penggunaan, Persepsi Kredibilitas dan Persepsi Harga Secara Simultan pada Niat Nasabah Menggunakan Mobile Banking

Berdasarkan hasil analisis penelitian secara simultan atau secara bersamasama yang diperoleh melalui uji $\mathrm{F}$ bahwa nilai signifikan 0,00<0,05 yang berarti Persepsi Kemudahan Penggunaan, Persepsi Kredibilitas, dan Persepsi Harga bersama-sama berpengaruh secara signifikan terhadap niat nasabah menggunakan layanan mobile banking Bank Syariah Mandiri.

Dengan demikian hipotesis yang menyatakan bahwa apakah Persepsi Kemudahan Penggunaan, Persepsi Kredibilitas, dan Persepsi Harga berpengaruh signifikan secara simultan terhadap niat nasabah menggunakan layanan mobile banking Bank Syariah Mandiri diterima. Hasil pengujian hipotesis ini sesuai dengan pernyataan dari Luarn et al (2005) bahwa Persepsi Kemudahan Penggunaan, Persepsi Kredibilitas, dan Persepsi Harga memiliki pengaruh signifikan terhadap niat nasabah menggunakan mobile banking.

b. Pengaruh Persepsi Kemudahan Penggunaan, Persepsi Kredibilitas dan Persepsi Harga Secara Parsial pada Niat Nasabah Menggunakan Mobile Banking

1. Pengaruh Persepsi Kemudahan Penggunaan pada Niat Nasabah

\section{Menggunakan Mobile Banking}

Hasil penelitian menunjukkan bahwa persepsi kemudahan penggunaan berpengaruh signifikan terhadap niat nasabah menggunakan mobile banking dengan tingkat signifikan sebesar 0,002 nilai ini lebih kecil dari 0,05. Oleh karena tingkat signifikansi yang lebih kecil dari 0,05 maka persepsi kemudahan penggunaan berpengaruh secara signifikan terhadap niat nasabah menggunakan mobile banking. Diantara variabel-variabel bebas yang lain diketahui bahwa variabel persepsi kemudahan penggunaan mempunyai pengaruh yang paling besar tehadap niat nasabah menggunakan layanan mobile banking dengan nilai rata-rata nilai persepsi kemudahan sebesar 3,4 yang termasuk dalam kategori sangat setuju.

Hasil penelitian ini didukung dengan penelitian dari Luarn et al (2005) yang menyatakan bahwa kemudahan 
Ramadhan, et al/Jurnal Ekonomi Syariah Teori dan Terapan Vol. 4 No. 6 Juni 2017: 478-492; PERSEPSI KEMUDAHAN PENGGUNAAN, PERSEPSI KREDIBILITAS, DAN PERSEPSI HARGA TERHADAP NIAT NABASAH MENGGUNAKAN LAYANAN MOBILE BANKING (STUDI KASUS PADA BANK SYARIAH MANDIRI SURABAYA)

penggunaan berpengaruh signifikan terhadap niat untuk menggunakan mobile banking. Berdasarkan pernyataan di atas dapat diartikan bahwa kemudahan penggunaan dapat mempengaruhi niat seseorang untuk menggunakan mobile banking jika dirasa sistem tersebut dapat memberikan kemudahan dalam penggunaannya. Sebagamana telah dijelaskan dalam AlBaqarah ayat 185:

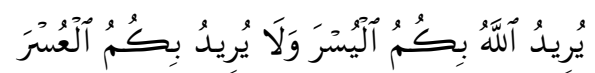

yurīdullāhu bikumulyusra walā yurīdu bikumukusra

"Allah menghendaki kemudahan bagimu, dan tidak menghendaki kesukaran bagimu".

\section{Pengaruh Persepsi Kredibilitas pada Niat}

\section{Nasabah Menggunakan Mobile Banking}

Hasil penelitian menunjukkan bahwa persepsi kredibilitas berpengaruh signifikan terhadap niat nasabah menggunakan mobile banking dengan tingkat signifikan sebesar 0,028 nilai ini lebih kecil dari 0,05. Oleh karena tingkat signifikansi yang lebih kecil dari 0,05 maka persepsi kredibilitas berpengaruh secara signifikan terhadap niat nasabah menggunakan mobile banking. Variabel persepsi kredibilitas mempunyai pengaruh terbesar kedua dengan nilai rata-rata sebesar 3,26 yang termasuk dalam kategori sangat setuju.

Hasil penelitian ini didukung dengan penelitian dari Wang et al (2003) yang menemukan hubungan langsung yang signifikan antara kredibilitas dan niat perilaku untuk menggunakan sistem informasi yang berupa mobile banking.
Berdasarkan pernyataan diatas dapat ditarik kesimpulan bahwa kredibilitas dapat mempengaruhi niat seseorang untuk menggunakan mobile banking jika sistem tersebut dapat memberikan keamanan pada saat bertransaksi dan menjaga data pribadi nasabah.

Pada $\mathrm{PC}_{1}$ merupakan indikator paling rendah diantara indikator PC lainnya yaitu menggunakan layanan mobile banking dapat menjaga privasi atau tidak membocorkan informasi pribadi nasabah. Rendahnya indikator tersebut dikarenakan masih ada beberapa nasabah yang kurang yakin dengan sistem keamanan dari mobile banking itu sendiri. Mengingat fasilitas bank berbasis online di Indonesia masih sering terjadi pembobolan data nasabah. Bank Syariah Mandiri sebagai lembaga kevangan yang tidak hanya mementingkan keuntungan saja namun juga harus menjaga amanah yang dipercayakan oleh nasabah dengan melindungi nasabah dari tindakan penipuan dan pencurian data sehingga nasabah merasa nyaman menggunakan fasilitas yang diberikan oleh pihak Bank. Menurut Kartajaya dan Sula, (2006:165) amanah dapat dipahami dengan makna terpercaya, bertanggung jawab dan juga bermakna keinginan untuk memenuhi sesuatu sesuai dengan ketentuan. Islam mengajarkan kepada setiap muslim untuk memegang teguh amanah yang telah diberikan kepadanya. Allah SWT berfirman bahwa orang-orang yang beruntung adalah mereka yang memelihara segala 
Ramadhan, et al/Jurnal Ekonomi Syariah Teori dan Terapan Vol. 4 No. 6 Juni 2017: 478-492; PERSEPSI KEMUDAHAN PENGGUNAAN, PERSEPSI KREDIBILITAS, DAN PERSEPSI HARGA TERHADAP NIAT NABASAH MENGGUNAKAN LAYANAN MOBILE BANKING (STUDI KASUS PADA BANK SYARIAH MANDIRI SURABAYA)

amanah yang telah diberikan kepadanya, sebagaimana dijelaskan dalam Qs. Al-Mu'minun (23): 8:

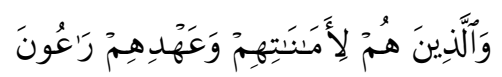

Wa'l-ladzinahum li- amānātihim wa'ahdihim rā'ūn

"dan (sungguh beruntung) orang-orang yang memelihara amanat-amanat dan janjinya"

Berdasarkan ayat diatas Bank syariah harus menerapkan layanan sesuai dengan prinsip syariah yaitu dengan menjaga amanah dengan memperhatikan kualitas pelayanan dan keamanan kepada nasabahnya sehingga memiliki kredibilitas yang tinggi.

\section{Pengaruh Persepsi Harga pada Niat}

\section{Nasabah Menggunakan Mobile Banking}

Hasil penelitian menunjukkan bahwa persepsi harga berpengaruh signifikan terhadap minat menggunakan mobile banking dengan tingkat signifikan sebesar 0,006 nilai ini lebih kecil dari 0,05. Oleh karena tingkat signifikansi yang lebih kecil dari 0,05 maka persepsi harga yang dikenakan berpengaruh secara signifikan terhadap Niat nasabah menggunakan mobile banking. Variabel ini mempunyai pengaruh paling kecil dengan nilai ratarata sebesar 3,23 yang termasuk dalam kategori setuju.

Hasil penelitian ini didukung dengan penelitian dari Eva Roviana (2015) yang menyatakan bahwa persepsi harga mempunyai pengaruh signifikan terhadap niat menggunakan mobile banking. Serta pendapat dari Kasmir (2004) yang menyatakan bagi konsumen harga merupakan faktor yang menentukan dalam pengambilan keputusan untuk membeli suatu produk atau tidak. Konsumen memutuskan membeli suatu produk jika manfaat yang dirasakan lebih besar atau sama dengan yang dikeluarkan untuk mendapatkannya. Berdasarkan pernyataan diatas dapat ditarik kesimpulan bahwa persepsi harga dapat mempengaruhi niat seseorang untuk menggunakan mobile banking jika manfaat yang dirasakan lebih besar atau sama dengan yang dikeluarkan untuk mendapatkannya.

Pada indikator $\mathrm{PP}_{1}$ merupakan indikator dengan nilai terendah, menurut responden yaitu tarif yang dikenakan dalam menggunakan mobile banking sepadan dengan kualitas yang diterima. Apabila harga tidak disesuaikan dengan produk dengan tendensi mencari keuntungan bagi pihak produsen atas harta konsumen, maka hal tersebut akan bertentangan dengan ajaran Islam yang telah tertulis pada Al-Qur' an surat An-Nisa' ayat 29 :

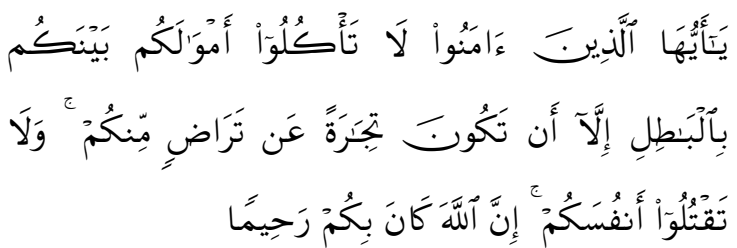

Yā ayyuhā allażina 'āmanū lā ta'kulū amwālakum baynakum bilbāțili illā 'an takūna tijāratan 'an tarāḍin minkum walā taqtulū 'anfusakum inna Allaha kāna bikum rahīmān

"Hai orang-orang yang beriman, janganlah kamu saling memakan harta sesamamu dengan jalan yang batil, kecuali dengan jalan perniagaan yang Berlaku dengan suka sama-suka di antara kamu. dan janganlah kamu membunuh dirimu, sesungguhnya Allah adalah Maha Penyayang kepadamu" (QS. An Nisa': 29). 
Ramadhan, et al/Jurnal Ekonomi Syariah Teori dan Terapan Vol. 4 No. 6 Juni 2017: 478-492; PERSEPSI KEMUDAHAN PENGGUNAAN, PERSEPSI KREDIBILITAS, DAN PERSEPSI HARGA TERHADAP NIAT NABASAH MENGGUNAKAN LAYANAN MOBILE BANKING (STUDI KASUS PADA BANK SYARIAH MANDIRI SURABAYA)

Ini merupakan masukan bagi Bank Syariah Mandiri untuk lebih meningkatkan kualitas yang diberikan. Jika kualitas produknya bagus, harganya tentu bisa tinggi. Sebaliknya jika seseorang telah mengetahui keburukan yang ada dibalik peroduk yang ditawarkan, harganya pun harus disesuaikan dengan kondisi produk tersebut (Kartajaya, 2006: 178).

\section{SIMPULAN DAN SARAN}

Berdasarkan hasil pengolahan data dengan menggunakan regresi linear berganda dan pembahasan yang telah dilakukan sebelumnya, dapat diambil kesimpulan bahwa:

1. Persepsi kemudahan penggunaan, persepsi kredibilitas, dan persepsi harga berpengaruh secara simultan terhadap niat nasabah menggunakan mobile banking Bank Syariah Mandiri.

2. Persepsi kemudahan penggunaan, persepsi kredibilitas, dan persepsi harga berpengaruh secara parsial terhadap niat nasabah menggunakan mobile banking Bank Syariah Mandiri.

3. Persepsi kemudahan penggunaan memiliki pengaruh paling dominan berpengaruh terhadap niat nasabah menggunakan mobile banking.

Saran bagi perusahaan, diharapkan untuk tetap mempertahankan kemudahan dalam pengoperasiannya; diharapkan untuk lebih meningkatkan sistem keamanan untuk mencagah terhadinya tindak kejahatan melalui layanan mobile banking, sehingga nasabah akan merasa aman dalam bertransaksi serta privasi data nasabah terjaga sehingga meningkatkan minat nasabah untuk menggunakan mobile banking; dan diharapkan untuk lebih meningkatkan kualitas layanan yang diberikan.

Penelitian ini hanya terbatas pada satu bank yaitu Bank Syariah Mandiri di Surabaya, diharapkan untuk penelitian selanjutnya tidak hanya terbatas pada satu obyek penelitian namun bisa menambah dengan Bank Syariah lainnya. Selain itu, penelitian selanjutnya diharapkan untuk melakukan penelitian pada pengguna nyata (actual use) suatu teknologi informasi atau melakukan penelitian pada teknologi informasi lainnya dengan menggunakan teori dasar penerimaan teknologi dan menambahkan perspektif syariah.

\section{DAFTAR REFERENSI}

Ajzen, I. 1991. The theory of planned behavior. Organizational behavior and human decision processes, 50(2), 179211.

(https://cas.hse.ru/data/816/479/1225/ Oct\%2019\%20Cited\%20\%231\%20Manag e\%20THE\%20THEORY\%20OF\%2OPLANNE D\%2OBEHAVIOR.pdf, diakses pada 8 Mei 2015).

Augusty, Ferdinand. 2006. Metode Penelitian Manajemen: pedoman penelitian untuk Penulisan Skripsi, Tesis dan Disertasi llmu manajemen. Semarang: Badan Penerbit Universitas Diponegoro.

Davis, F.D, Bagozzi R. P., dan Warshaw P. R. 1989. User Acceptance of Computer Technology: A Comparison of Two Theoretical Models. Management Science, (online), Vol. 35 No. 8: pp 982- 
Ramadhan, et al/Jurnal Ekonomi Syariah Teori dan Terapan Vol. 4 No. 6 Juni 2017: 478-492; PERSEPSI KEMUDAHAN PENGGUNAAN, PERSEPSI KREDIBILITAS, DAN PERSEPSI HARGA TERHADAP NIAT NABASAH MENGGUNAKAN LAYANAN MOBILE BANKING (STUDI KASUS PADA BANK SYARIAH MANDIRI SURABAYA)

1003,

(http://home.hia.no/fwahid01/thesis/art icles/davis\%20et\%0al\%01989.pdf, diakses 20 April 2015).

Davis, F.D. 1989. Perceived Usefulness, Perceived Ease of Use, and User Acceptance of Information Technology. MIS Quarterly, (online), Vol. 13 No. 5: pp319-339, (http://www.cba.hawaii.edu/chismar?! TM704/DavisTAM1989.pdf, diakses 20 April 2015).

Kartajaya, Hermanawan dan Muhammad Syakir Sula. 2006. Syariah Marketing. Bandung:Mizan.

Kasmir. 2004. Pemasaran Bank. Jakarta: Kencana.

Kotler, Philip, dan Kevin Lane Keller. 2001. Marketing Management, 10. Canada: Pearson Education.

Kusumo, Hanung Cokro. 2010. Analisis Penerimaan Mobile Banking (MBanking) Dengan Kerumitan (Complexity) Sebagai Variabel Eksternal Dengan Menggunakan Pendekatan Technology Acceptance Model (TAM). Skripsi tidak diterbitkan. Fakultas Ekonomi-Universitas Sebelas Maret Surakarta.

Luarn, P., \& Lin, H. H. (2005). Toward an understanding of the behavioral intention to use mobile banking. Computers in human behavior, $21(6)$, 873-891. (www.elsevier.com/locate/comphumb eh, diakses pada 17 Mei 2015).

Maharsi, Sri dan Yuliani Mulyadi. 2007. Faktor-Faktor yang Mempengaruhi Minat Nasabah Menggunakan Internet Banking dengan Menggunakan Kerangka Technology Acceptance Model (TAM). Jurnal Akuntansi dan Keuangan (online), Vol. 9, No. 1, Mei 2007, hal

18-28, (http://puslit.petra.ac.id/journals/accou nting, diakses 7 Agustus 2015).

Mowen J.C. 1993. Consumer behavior. Third Edition. New York: Macmillan Publishing Company.
Roviana, Eva. 2015. Analisis Pengaruh Persepsi Harga atau Margin dan Kualitas Pelayanan Terhadap Minat Anggota dalam Membeli Produk Pembiayaan Murabahah di Koperasi Jasa Keuangan Syariah (Studi Kasus BMT AMAL MULIA). Skripsi tidak diterbitkan. Sekolah Tinggi Agama Islam Negeri Salatiga.

Sugiyono, 2012. Metode Penelitian kuantitatif dan Kualitatif dan R\&D. Bandung: Alfabeta.

Tsai, Wen-Chia. 2012. A Study of Consumer Behavioral Intention to Use E-Book: The Technology Acceptance Model Perspective. Innovate Marketing, Vol. 8, Issue 4, pg 55. (http://businessperspectives.org/journal s_free/im/2012/

im_en_2012_04_Tsai.pdf, diakses pada 24 Februari 2016).

Wang, Y.S, Wang Y,M, Lin, H.H., and Tang, T.I 2003. Determinants of user acceptance of internet banking: An empirical Study. International journal of Service Industry management (online journal from Proquest), Vol.14, Iss.5, pg. 501.

(www.emeraldinsight.com/researchgister, diakses pada 7 Agustus 2015).

Zeithamal, Valarie A. 1988. Consumer Perception of Price, Qualitiy, and Value: A Means-End Model and Synthesis of Evidence. Journal of Marketing, (online), Vol. 52, 2-22, (www.emeraldlibrary.com, diakses 5 Desember 2015). 